\title{
The Elizabethan Idea of Empire
}

\section{Citation}

Armitage, David. 2004. The Elizabethan idea of empire. Transactions of the Royal Historical Society (Sixth Series) 14: 269-277.

\section{Published Version}

http://dx.doi.org/10.1017/S008044010400012X

\section{Permanent link}

http://nrs.harvard.edu/urn-3:HUL.InstRepos:3382856

\section{Terms of Use}

This article was downloaded from Harvard University's DASH repository, and is made available under the terms and conditions applicable to Other Posted Material, as set forth at http:// nrs.harvard.edu/urn-3:HUL.InstRepos:dash.current.terms-of-use\#LAA

\section{Share Your Story}

The Harvard community has made this article openly available.

Please share how this access benefits you. Submit a story.

Accessibility 


\title{
THE ELIZABETHAN IDEA OF EMPIRE
}

\section{By David Armitage}

\begin{abstract}
This paper argues that the English idea of empire in the reign of Elizabeth I was derivative, belated and incoherent. Its sources were classical and continental rather than indigenous. It arose more than a century after the Scottish monarchy had elaborated its own conception of empire. Moreover, it expressed a sense of backwardness, isolation and anxiety that mirrored the English failure to establish any permanent settlements in the Atlantic world. As a result, any balance sheet of empire drawn up on Elizabeth's death in 1603 would have valued prospects in the Mediterranean and the East Indies more highly than possibilities in the Americas.
\end{abstract}

'Between 1453 and $1558, \ldots$ England, without realizing it at the time, became (if I may be forgiven the expression) an island, in other words an autonomous unit distinct from continental Europe', wrote Fernand Braudel.' $155^{8}$ was a terminus ad quem less for the accession of a Protestant queen to the English throne than for the loss of Calais, the English crown's last territorial toehold on the European Continent. Braudel's remark obviously ignored Scotland, England's insular neighbour to the north. It overlooked Ireland, England's semi-independent dependency to the west. And it also assumed that England's formal geographical displacement from 'Europe' could be taken to imply its geopolitical disengagement as well. However, Braudel's point was not that 'England' became wholly isolated from the rest of the world and sufficient unto itself; rather, its detachment from its traditional trading links with Europe opened it up to a grander destiny as a central player in the emergent Atlantic and global economy. Insularity thereby became the precondition for ever-expanding interchange.

Braudel was not alone among post-war commentators in noting 'English' insularity and its relation to maritime expansion. For example, the German jurist and political philosopher Carl Schmitt remarked in his astonishing opus, The Nomos of the Earth in the International Law of the Jus Publicum Europaeum (1950), that, after the late fifteenth-century division

'Fernand Braudel, Civilization and Capitalism (1979; 3 vols., trans. Siân Reynolds, New York, $19^{82-4}$ ), 111, 353. My thanks to David Harris Sacks for this reference. 
of the globe by the Alexandrine Bulls and the treaty of Tordesillas,

land and sea were divided into too separate and distinct global orders within the Eurocentric world order that arose in the sixteenth century... The connecting link between the different orders of land and sea became the island of England... The English island remained a part or rather the center of this European planetary order, but simultaneously distanced herself from the European continent and assumed the world-historical intermediary position that for more than three centuries made her of Europe, but not in Europe'. ${ }^{2}$

Braudel's and Schmitt's conceptions of English insularity shed new light on the processes classically examined in A. L. Rowse's The Expansion of Elizabethan England (1955). ${ }^{3}$ How could insular introversion become imperial expansion, and how could navel-gazing turn outward into empire-building? The answer was clear to Schmitt: England was the Hegelian harbinger of a new global order, separate from the Continent, to be sure, but unequalled in its capacity to inaugurate a wholly new 'planetary order'.

Braudel's insular empire and Schmitt's inexorable empire were two sides of the same coin. Both represented different facets of enduring and widespread ideas of England, of empire, and of the reign of Elizabeth I as pivotal for both English and imperial history. Beneath both their conceptions lay the notion of England as an inside-out empire. For both of them, England formed a shrunken insular core, detached both from continental Europe and from the surrounding Atlantic archipelago. This empire was English long before it became a British - or, to be precise, an Anglo-British ${ }^{4}$ - empire. In due course, it would be defined as an empire of the seas, distinct from the 'island' of England, cut off by the River Tweed from Scotland, by St George's Channel from Ireland and by the English Channel from the Continent, yet by the end of the Napoleonic Wars it would expand its wooden walls out across the waves to encompass the whole globe. As Schmitt had put it in an earlier work, Land and Sea (I942), 'During the forty-five years of [Elizabeth's] reign ... all the seas of the world converged upon the English Isle.'5

Braudel, Schmitt and Rowse, among many others, were the diverse heirs to an enduring idea of the British Empire as characteristically and uniquely Protestant, commercial, maritime and free. On this conception,

${ }^{2}$ Carl Schmit, The Nomos of the Earth in the International Law of the Jus Publicum Europaeum (I950; trans. G. L. Ulmen, New York, 2003), I73.

3 A. L. Rowse, The Expansion of Elizabethan England (1955; repr. and introd. Michael Portillo, Basingstoke, 2003).

4 Roger A. Mason, "The Scottish Reformation and the Origins of Anglo-British Imperialism', in Scots and Britons: Scottish Political Thought and the Union of 1603 , ed. Roger A. Mason (Cambridge, 1994), 16-86; Colin Kidd, Subverting Scotland's Past: Scottish Whig Historians and the Creation of an Anglo-British Identity, 1689- c. 1830 (Cambridge, 1993).

${ }^{5}$ Carl Schmitt, Land and Sea (r942; trans. Simona Draghici, Washington, DC, 1997), 23. 
island 'England' sat at the centre of an empire of the seas, separated by a cordon sanitaire from the imperial diseases that infected all other European empires. The British Empire was the first post-Reformation empire. It was an empire of commerce not conquest, defended by its navy rather than being propagated by an army. It was therefore a benign empire, conducted at healthy distances from the metropolis and posing no threat to domestic liberties while at the same time carrying 'English' liberty abroad along with the common law and a tolerant and non-coercive religion. ${ }^{6}$

This conception of the British Empire had sixteenth- and seventeenthcentury roots, though it first flourished in fully recognisable form during the I730s and 1740s. It reached its apotheosis in the mid-nineteenth century, in the language of J. A. Froude's 'England's Forgotten Worthies' $\left(185^{2}\right)$ :

The England of the Catholic Hierarchy and the Norman Baron, was to cast its shell and to become the England of free thought and commerce and manufacture, which was to plough the ocean with its navies, and sow its colonies over the globe; and the first thunder birth of these enormous forces and the flash of the earliest achievements of the new era roll and glitter through the forty years of the reign of Elizabeth with a grandeur which, when once its history is written, will be seen to be among the most sublime phenomena which the earth as yet has witnessed.?

Froude provided an enduring vision of the inside-out empire congenial to later ages of imperial introversion and isolationism. It implied that the British Empire was distinct from the English state but still an extension of the English nation; that it was a product of westward 'expansion' in a straight line across the Atlantic, from England via Ireland to the American colonies; and that it was defined against Europe and the other European empires.

If part of an empire's ideology is getting its history wrong, then this idea of empire was exemplary in its errors. The Tudor idea of empire was in fact a product and extension of Tudor state-formation. ${ }^{8}$ Its matrix was the triangular set of relationships among England, Scotland and Ireland. It was also what post-colonial theorists would call a 'derivative discourse' that was inconceivable without contemporary European contexts and comparisons. ${ }^{9}$ It could hardly have been anything other than derivative. The language of empire was common to all claims to authority, sovereignty and territory in early modern Europe and all

${ }^{6}$ David Armitage, The Ideological Onigins of the British Empire (Cambridge, 200o).

7 [J. A. Froude], 'England's Forgotten Worthies', Westminster Review, new series, 2, 1 (1852), 22.

${ }^{8}$ Michael J. Braddick, State Formation in Early Modern England, c. 1550-170o (Cambridge, 2000).

${ }^{9}$ Partha Chatterjee, Nationalist Thought and the Colonial World: A Derivative Discourse Minneapolis, 1993). 
such claims derived ultimately from Roman conceptions of imperium. ${ }^{10}$ Three such conceptions had been derived from the Roman legacy by the late sixteenth century. In the first, cmpire meant simply authority or sovereignty. In the second, it meant the territory over which such authority or sovereignty was claimed. In the third, it meant rule over many dominions, either descriptively, as a term denoting 'multiple' or 'composite' monarchy; or evaluatively, as a shorthand for domineering 'universal' monarchy." Each of these three conceptions had its own peculiar afterlife in Elizabethan England.

The idea of empire as sovereignty was the very foundation of the Tudor state's claim to independent authority. It derived from the famous claim, made in the preamble to the 1533 Act in Restraint of Appeals, that 'this realm of England is an empire'. The claim to recognise no superior authority necessarily possessed a territorial dimension. The Henrician acts of 1536 and 1543 incorporating Wales into the Tudor state and the Irish parliament's declaration of Henry VIII's kingship (rather than simply lordship) over Ireland in 1541 confirmed this. Tudor England after the Reformation had become, in short order, a composite monarchy (by incorporating Wales) and a multiple kingdom (by the addition of the crown of Ireland to Henry's regal appurtenances). In retrospect, it can be seen that these developments made possible the first claims to an 'empire of Great Britain' which were made by propagandists for English dominion over Scotland in the I540s on behalf of Henry VIII and then on behalf of his son, Edward VI. Indeed, the language both of 'British' empire and of 'colonies' as the cultural expression of that empire both arose first in the context of Anglo-Scottish relations and hence on the island of Great Britain, not in Ireland, the Caribbean or North America. ${ }^{12}$ Elizabeth would not follow her father or her brother's regents in making such aggressive claims to suzerainty over Scotland though there were those, like John Dee and Edmund Spenser, who would make such claims on her behalf from the 157 os to the 1590 . The expansion of Elizabethan England to incorporate Scotland would only be achieved after her death and by a Scottish king, James VI, when he acquired the crowns of England and Ireland by his accession to the English throne as James $I$ in 1603 .

That it should have been a Scottish king who created the kingdom of Great Britain was less ironic than inevitable. After all, it had been the fifteenth-century Stewart monarchy in Scotland rather than the

${ }^{10} \mathrm{~J}$. S. Richardson, 'Imperium Romanum: Empire and the Languages of Power', Fournal of Roman Studies, 81 (1991), 1-9.

"Anthony Pagden, Lords of All the World: Ideologies of Empire in Spain, Britain and France c. $1500-c .1800$ (New Haven, 1995), 12-17.

${ }^{12}$ David Armitage, 'Making the Empire British: Scotland in the Atlantic Wortd, $154^{2-}$ 1707', Past and Present, 155 (1997), 39-41. 
sixteenth-century Tudor monarchy in England that had first pioneered the language of empire in Britain. ${ }^{13}$ Henry VIII's assertion that his realm was an empire looks distinctly belated when compared to the claim made on behalf of James III of Scotland, more than half a century earlier in 1469 , that he possessed 'ful Jurisdictioune and fre Impire' within his realm.14 As later in England, so in Scotland did an abstract assertion of jurisdictional independence rapidly become the basis of a set of territorial claims, in James III's case to the Orkneys and the Shetlands, to land in France and, later, to the Western Isles of Scotland. These Scottish appeals to the language of empire revealed, perhaps even more clearly than later English usage, that this was a pan-European discourse rather than an autochthonous product of Britain. Their origins lay in a French legal discourse of sovereignty which, in turn, derived from the Europe-wide revival of Roman civil law since the twelfth century. ${ }^{15}$ There was nothing peculiarly Scottish about the particular language in which this particular Scottish declaration of independence was couched. This was, of course, even more strikingly true of the later English language of empire deployed in defence of the Tudor church and state.

The Elizabethan idea of empire was belated and unelaborated, even in comparison with the Scottish idea of empire, which had found expression in law and statute, coinage and architecture, decades before any similar manifestations in England. ${ }^{16}$ The backwardness and derivativeness of the Elizabethan imperial idea appear even more starkly when it is compared with continental European conceptions. The classic treatment of those conceptions and their relationship with Elizabethan imperial imagery and ideology remains Frances Yates's Astraea: The Imperial Theme in the Sixteenth Century (1975). Despite all her extraordinary efforts to show how various and fertile that relationship was, Yates offered little evidence that the traffic from England to the Continent was in any way comparable to that travelling from the Continent to England. Indeed, she acknowledged that, though the 'imperial theme' in Elizabethan England was an index of nascent nationalism, it was nonetheless forged almost entirely from alien ancient and modern materials, from Virgil to Giordano Bruno. She took

${ }^{13}$ Roger A. Mason, 'This Realm of Scotland Is an Empire? Imperial Ideas and Iconography in Early Renaissance Scotland', in Church, Chronicle and Learning in Medieval and Early Renaissance Scotland: Essays Presented to Donald Watt, ed. Barbara E. Crawford (Edinburgh, 1999), $77-95$.

${ }^{{ }^{4}}$ Acts of the Parliaments of Scotland, ed. Thomas Thomson and Cosmo Innes ( 12 vols., Edinburgh, 1814-75), I, 95.

${ }^{15}$ Jacques Krynen, L'empire du roi: idées et croyances politiques en France, XIJIe-Xue siècle (Paris, 1993), $3^{88-414}$.

${ }^{16}$ Roger A. Mason, 'Regnum et Imperium: Humanism and the Political Culture of Early Renaissance Scotland', in Roger A. Mason, Kingship and Commonweal: Political Thought in Renaissance and Reformation Scolland (East Linton, 1998), $126-38$. 
this fact to be 'a measure of the sense of isolation which had at all costs to find a symbol strong enough to provide a feeling of spiritual security in the face of the break with the rest of Christendom', especially after the papal excommunication of Elizabeth in $1570 .{ }^{17}$

Yates famously found the key to the Elizabethan imperial theme in the reformist apocalypticism of Virgil's Fourth Eclogue, with its vision of the Virgin returning to the earth along with the age of gold (iam redit et Virgo, redeunt Saturnia regna). ${ }^{18}$ Perhaps a better motto, because one more frequently cited by contemporaries, would have been a line from Virgil's First Eclogue describing the isolated Britons (toto divisos orbe Britannos): as Ben Jonson translated it in 1604 , 'this empire is a world divided from the world'.${ }^{19}$ English writers quoted Virgil's words in self-congratulation at their autonomy and indifference to territorial expansion, and at their distance from the bloody struggles for land and dominion being fought in continental Europe. Until the late 1570 and early 1580 , this reinforced an idea of empire that was conservative, backward-looking and fundamentally defensive rather than expansive. This was a conception of a British Empire derived from the legacy of the British king Brutus, dangerous in its effects on Britons (and others) and destined for inglorious collapse: in a nutshell, 'Brutish', nasty and short.

Any reference to a British Empire evoked an anglocentric vision derived from the anti-Celtic ethnography of Geoffrey of Monmouth in the twelfth century. This had provided the historical basis for English claims over Scotland in the 1540 s and underpinned the Elizabethan ideas of empire propagated by the Welsh antiquarian Humphrey Llwyd and the Welsh 'wizard' John Dee in the ${ }_{1570 s}$ and ${ }_{15} 80{ }^{20}{ }^{20}$ Dee envisaged 'this incomparable Brytish Empire' as reaching to the north-east coast of America and the coasts of France and Germany and derived these expansive claims from the exploits of King Arthur and the Welsh Prince Madoc, who had allegedly discovered America four centuries before Columbus. ${ }^{21}$

"Frances Yates, 'Queen Elizabeth I as Astraca', in Frances Yates, Astraea: The Imperial Theme in the Sixteenth Century (1975), 59 .

${ }^{18}$ Virgil, Eclogues, lV. 6; Yates, 'Queen Elizabeth I as Astraea,' $33^{-8 .}$

${ }^{19}$ Virgil, Eclogues, 1. 66; Ben Jonson, Part of the the King's Entertainment in Passing to his Coronation (1604), in Ben Fonson, ed. C. H. Herford, Percy Simpson and Evelyn Simpson (II vols., Oxford, 1925-52), VII, 84; Graham Parry, The Golden Age Restor'd: The Culture of the Stuart Court, $1603-42$ (Manchester, 1981), 4 .

${ }^{20}$ Bruce Ward Henry, John Dee, Humphrey Llwyd, and the Name "British Empire", Huntington Library Quarterly, 35 (1972), 189-9o.

${ }^{2 t}$ John Dee, General and Rare Memorials Pertayning to the Perfect Arte of Navigation (1577), 8; Dee, ' $\theta$ A $\Lambda$ \ATOKPATIA BPETTANIKH' (8 Sept. I597), British Library, Harleian MS 249, fos. 95-105; Ken MacMillan, 'Discourses on History, Geography, and Law: John Dee and the Limits of the British Empire, 1576-80,' Canadian Journal of History, $3^{6}$ (2001), $1-25$. 
Such visions, despite being grounded on a firm conception of first discovery and defended with legal-humanist justifications from history, far outran the ambitions of Elizabeth or most of her councillors. As David Hume would point out in his mid-eighteenth-century History of England, Elizabeth herself 'had done little more than give a name to the continent of Virginia'. ${ }^{22}$ Elizabethan panegyric, whether in poetry, prose or paint, portrayed the queen as 'Elizabeth, great Empresse of the world, / Britanias Atlas, Star of Englands globe' (in the words of the poet George Peele) or addressed her as 'the most High, Mighty and Magnificent Empress... Elizabeth by the Grace of God, Queen of England, France and Ireland, and of Virginia' (as Edmund Spenser put it in the dedication to his Faerie Queene in 1596 ). ${ }^{23}$ However, such panegyrics were expressed upwards, as flattery, rather than downwards, as propaganda. ${ }^{24}$

There is no evidence that the queen possessed any such exalted ideas of her own imperial status. At least one of her subjects, when interrogated by the Inquisition in Lima, argued that it was the queen herself who discouraged English expansion in the Americas: 'Witness understands that if the Queen should die, many will come and pass through the Strait [of Magellan] and found settlements. The Queen is the cause that no one comes. ${ }^{\prime 2}$ The contrast here with the comprehensive apocalyptic imperial vision of her adversary Philip II of Spain is especially striking. ${ }^{26}$ The few fragments of evidence we do have suggest that Elizabeth's own idea of empire was indeed tinged with the sense of isolation, backwardness and anxiety felt by all but the most fulsomely flattering of her subjects. For example, her reaction upon being presented with the Hugucnot cartographer Emery Molyneux's terrestrial globe in 1592 was reported as follows:

she was pleased to descant, The whole earth, a present for a Prince; but with the Spanish King's leave, she said, alluding to his Emblem, a Spanish Genet, in spced upon the Globe of

${ }^{22}$ David Hume, The History of England (1762), ed. William B. Todd (6 vols., Indianapolis, $1983), v, 147$.

${ }^{23}$ George Peele, Polyhymnia (1590), sig. [A2]v; Edmund Spenser, The Faerie Queene (1596), sig. $[\mathrm{AI}] \mathrm{v}$.

${ }^{24}$ Sydney Anglo, Images of Tudor Kingship (1992), 127-8.

${ }^{25}$ 'Thomas Xerores, shipmaster', in 'The Declarations that Were Made by Captain John Oxenham and Other Englishmen... concerning the Exploration of the Strait of Magellan' (20 Feb. 1579/8o), in New Light on Drake: A Collection of Documents relating to his Voyage of Circumnavigation, $1577^{-1} 5^{80}$, ed. Zelia Nuttall (Hakluyt Society, second series, Xxxiv, 1914), II.

${ }^{26}$ Geoffrey Parker, The World Is Not Enough: The Imperial Vision of Philip II of Spain, Charles Edmondson Historical Lectures, 22 (Waco, TX, 2001); Parker, "The Place of Tudor England in the Messianic Vision of Philip II of Spain', Transactions of the Royal Historical Society, sixth series, 12 (2002), 167-221. 
the Earth, his fore-feet over-seaching, with this Motto, Non sufficit orbis [the world is not enough]. ${ }^{27}$

Her reaction indicated as much embattlement as defiance, as well as a reasonable assessment of England's chances of competing for geopolitical dominance with the Spanish Habsburgs. Similarly, her prayer on the sailing of the English expedition to the Azores in July 1597 expressed a more positive conception of England's aims: 'our just cause, not founded on pride's motion nor begun on malice-stock but, as Thou best knowest to whom naught is hid, grounded on just defence from wrongs, hate and bloody desire of conquest'. ${ }^{28}$ Such moral self-congratulation was, of course, something of a cheap luxury for a state without the resources to engage in large-scale conquest (as it had discovered repeatedly in Ireland). It was also a sign of a deep-rooted anxiety about the costs of conquest derived from classical sources such as Livy, Tacitus and Sallust, familiar to a well-trained humanist like Elizabeth. Such sources warned against the moral dangers of corruption arising from conquest and expansion, as when Robert Sidney ominously annotated his copy of Tacitus with a comment on 'the servitu[d]e under the Ro[mans]' experienced by the tribes of Britain. ${ }^{29}$

Such anxiety about the costs of empire, when combined with a lack of firm leadership from the top, left the English without any substantial or distinctive conception of empire for most, if not all, of Elizabeth's reign. Richard Hakluyt noted in $15^{82}$ that, 'since the first discoverie of America ... after so great conquests and plantings of the Spaniardes and Portingales there... wee of England could never have the grace to set fast footing in such fertill and temperate places, as are left as yet unpossessed by them'.$^{30}$ His life's work would be to collect the records of English overseas activity and, just as importantly, to translate the documents of other European enterprises, in order to inspire his countrymen to better efforts at overcoming their reluctance and backwardness. The instruments of that overcoming would mostly be imports from abroad: Huguenot pilots; Spanish navigational aids; Dutch, Flemish and German mapmakers, printers, engravers and painters. ${ }^{3 x}$ As one economic promoter stated of the

${ }^{27}$ William Sanderson, An Answer to a Scurrilous Pamphlet (1656), sig. [A3]v; Anna Maria Crino and Helen Wallis, 'New Research on the Molyneux Globes', Der Globusfreund, 35 (5987), 14 .

${ }^{26}$ Elizabeth I, Collected Works, ed. Leah S. Marcus, Janel Mueller and Mary Beth Rose (Chicago, 2000), 426 .

${ }^{29}$ Andrew Fitzmaurice, Humanism and America: An Intellectual History of English Colonisation, 1516-1625 (Cambridge, 2003); C. Cornelii Taciti Opera, ed. Justus Lipsius (Antwerp, 1585), 234-5, British Library shelfmark C. 142. e. 13 (annotation by Robert Sidney).

${ }^{30}$ Richard Hakluyt, Divers Voyages Touching the Discoverie of America $\left(\mathrm{I}_{5}^{82}\right)$, sig. $\$[\mathrm{x}] \mathrm{r}$.

${ }^{3}$ Helen Wallis, 'Emigre Map-Makers in the Late I6th Century and the Protestant New World', Proceedings of the Huguenot Society of London, 24 (1985), 210-20; Sarah Tyacke, Before 
English in 1577 , 'We ought to favor the Strangers from whom we learned so grete benefits... because we are not so good devisers as followers of others'. ${ }^{32}$ Such a judgement would fit equally well the English overseas project as it would the cloth industry to which he was referring.

Yet even with the forceful manipulation and exploitation of continental European resources, the Elizabethan age ended with an empire nowhere, its monuments the wrecked hopes of lost colonies scattered along the western Atlantic littoral from Kodlunarn Island in the Arctic circle to Ralegh's Guiana in the tropics. ${ }^{33}$ The geographer and bishop George Abbot's epitaph for Virginia in 1599 could have been applied just as readily to any of these failed enterprises: 'this voyage beeing enterprised on the charge of private men: and not thorowly beeing followed by the state: the possession of this Virginia is nowe discontinued, and the country is at present left to the old inhabitants'. ${ }^{34}$ Any risk assessment of English prospects in $\mathrm{I}_{603}$ would surely have found those prospects most promising in the Mediterranean, Asia and the East Indies, not in the Atlantic, America or the West Indies. Yet, as such an assessment would also have shown, by 1603 it was no longer sufficient to consider the origins of England's empire outside their archipelagic, European and global contexts. In this respect, Braudel and Schmitt were correct: England was never an island, entire of itself.

Empire: The English World Picture in the Sixteenth and Seventeenth Centuries, Hakiugt Society Annual Lecture (2000) (200r), 21.

${ }^{32} \mathrm{John}$ Leake, quoted in Anthony Wells-Cole, Art and Decoration in Elizabeth and Jacobean England: The Influence of Continental Prints, 1558-1625 (New Haven, 1997), 3.

${ }^{33}$ Jeffrey Knapp, An Empire Nowhere: England, America, and Literature from Utopia to The Templest (Berkeley, 1992); Joyce E. Chaplin, Subject Matter: Tectnology, the Body, and Science on the AngloAmerican Frontier, 1500-1676 (Cambridge, MA, 2001), 46-59; English and Inish Settement on the River Amazon, 1550-1640, ed. Joyce Lorimer (Hakluyt Society, second serics, CLxxi, 1989).

${ }^{34}$ George Abbot, $A$ Briefe Description of the Whole Warld (1599), sig. [D8]: 